\title{
Kuantifikasi Gen VDR Pada Diabetes Melitus Tipe 2 Dengan Metode Real-Time Polymerase Chain Reaction
}

\author{
*Fini Ainun Qolbi Wasdili1), Sitti Romlah"1), Shintia Novianty ${ }^{1)}$
}

${ }^{1}$ Program Studi TLM, Stikes Jenderal Achmad Yani Cimahi

*Correspondence Author: Fini Ainun Qolbi Wasdili, fini.ainun@gmail.com, Cimahi, Indonesia

\begin{abstract}
Abstrak
Diabetes melitus (DM) tipe 2 adalah penyakit yang ditandai dengan hiperglikemia akibat resistensi tubuh terhadap efek insulin yang diproduksi oleh sel $\beta$ pankreas. Pada lansia terjadi proses menua yang menyebabkan banyak perubahan fungsi organ tubuh. Defisiensi vitamin D dapat terjadi pada penderita DM tipe 2 dan mempercepat resistensi insulin. Vitamin D berperan pada imunomodulator yang melindungi terhadap kejadian DM melalui gen Vitamine D Receptor (VDR) yang diekspresikan pada sel penyaji antigen, sel T aktivasi dan sel $\beta$ pankreas. Jumlah VDR yang ada di dalam tubuh tergantung pada gen $V D R$ yang diekspresikan di dalam sel. Kuantifikasi peningkatan gen $V D R$ pada lansia DM tipe 2 dengan metode Real-Time PCR. Penelitian ini menggunakan metode deskriptif laboratorik. Spesimen terdiri dari darah lansia yang menderita DM tipe 2 dan darah lansia dengan kadar glukosa normal. Proses ekstraksi DNA dari darah menggunakan metode spin kolom, kemudian diamplifikasi dengan Real-Time PCR. Hasil Real-Time PCR dianalisis dengan menggunakan perhitungan rasio. Hasil penelitian nilai $\mathrm{Ct}$ normal adalah 21, sedangkan pada lansia penderita DM sangat bervariasi dengan nilai Ct paling kecil 15,22 dan nilai Ct paling tinggi 21,61. Disimpulkan terdapat variasi jumlah peningkatan gen VDR pada lansia penderita DM tipe 2.
\end{abstract}

Kata kunci : VDR, DM, Real-time PCR

\begin{abstract}
Diabetes mellitus (DM) type 2 is a disease characterized by hyperglycemia due to the body's resistance to the effects of insulin produced by pancreatic $\beta$ cells. In the elderly, there is a process of aging which causes many changes in the function of the body's organs. Vitamin $D$ deficiency can occur in people with type 2 diabetes and accelerates insulin resistance. Vitamin D acts as an immunomodulator that protects against the incidence of DM through the Vitamin D Receptor (VDR) gene which is expressed on antigen-presenting cells, activated T cells and pancreatic $\beta$ cells. The amount of VDR present in the body depends on the VDR gene that is expressed in the cells. The quantification of the increase in VDR genes in elderly with type 2 diabetes was measured with RealTime PCR method. This study used a laboratory descriptive method. The specimens consisted of the blood of the elderly suffering from type 2 diabetes and the blood of the elderly with normal glucose levels. DNA was extracted from blood with the spin column method, then amplified by Real-Time PCR. Real-Time PCR results were analyzed using ratio calculations. The results showed the normal Ct value was 21, while the elderly with DM varied greatly with the smallest $C t$ value of 15.22 and the highest $C t$ value of 21.61. It is concluded that there are variations in the number of increases in the VDR gene in elderly people with type 2 diabetes.
\end{abstract}

Keyword : VDR, DM, Real-time PCR

Open Journal System (OJS): journal.thamrin.ac.id

http://journal.thamrin.ac.id/index.php/anakes/issue/view/43 


\section{PENDAHULUAN}

Diabetes melitus (DM) tipe 2 adalah suatu penyakit yang ditandai dengan hiperglikemia akibat dari resistensi tubuh terhadap efek insulin yang diproduksi oleh sel $\beta$ pankreas. DM tipe 2 merupakan diabetes yang terjadi pada orang dewasa yang terjadi pada sekitar $80 \%$ pasien yang mengidap diabetes melitus. Prevalensi DM tipe 2 meningkat pada lanjut usia. Peningkatan jumlah penderita DM tipe 2 ini dipengaruhi oleh berbagai faktor, diantaranya adalah genetik, gaya hidup, usia, obesitas dan aktifitas fisik. Berdasarkan data Riskesdas Tahun 2018, prevalensi diabetes pada kelompok usia 45-54 tahun sebesar 3,9\%, 55-64 tahun $6,3 \%, 65-74$ tahun $6,0 \%$ dan $>75$ tahun sebesar 3,3\%. Dari data tersebut mengalami peningkatan dibandingkan dengan prevalensi DM tipe 2 pada tahun 2013 (Kementerian Kesehatan RI Badan Penelitian dan Pengembangan, 2018; Khairani, 2019).

Pada lansia terjadi proses menua yang menyebabkan banyak perubahan, salah satunya terjadi penurunan fungsi organ tubuh. Penurunan fungsi organ tubuh ini menyebabkan kerentanan terhadap berbagai penyakit. Salah satu yang terjadi adalah disfungsi organ yang terganggu, yaitu pada sistem pengaturan kadar glukosa darah. Gangguan pengaturan glukosa darah pada lansia meliputi tiga hal yaitu resistensi insulin, hilangnya pelepasan insulin fase pertama, dan peningkatan kadar glukosa darah postprandial. Seiring dengan proses penuaan semakin banyak lansia yang berisiko menderita Diabetes Melitus. Diabetes Melitus pada lansia umunya bersifat asimptomatik (Kurniawan, Bahrun, \& Darmawaty, 2012; Marinda, Suwandi, \& Karyus, 2016).

Resistensi insulin tidak terlepas dari peran Tumor Necrosis Factor- $\alpha$ (TNF- $\alpha$ ). Beberapa penelitian yang mengevaluasi fungsi imun pada pasien DM tipe 2, terdapat gangguan imunitas alami maupun imunitas adaptif. Beberapa gangguan tersebut antara lain berupa penurunan sekresi sitokin interleukin 1 (IL-1) dan interleukin 6 (IL-6) oleh sel neutrofil maupun monosit, penurunan mobilisasi, kemotaksis dan fagositosis oleh sel-sel fagosit, penurunan respons sel $\mathrm{T}$, peningkatan jumlah TNF- $\alpha$, dan gangguan imunitas humoral. Sehingga terganggunya sistem pengaturan kadar glukosa darah dan dapat terjadi downregulation enzim phosphoenolpyruvate carboxykinase yang diperlukan pada glukoneogenesis, sehingga terjadi peningkatan glukoneogenesis di hati (Lestari, 2011). 
Beberapa peneliti menemukan hubungan antara risiko penyakit DM dengan defisiensi vitamin D (Suryanto \& T, 2018). Menurut penelitian prevalensi defisiensi vitamin D pada pasien DM tipe 2 sebesar 49\% (Indra, Lydia, Purnamasari, \& Setiati, 2017). Penelitian yang menghubungkan vitamin D dengan DM menunjukkan bahwa resiko DM dapat meningkat pada orang dengan kadar vitamin D serum yang rendah (Khan H, Kunutsor S, Franco OH, 2013). Reseptor vitamin D (VDR) adalah kelompok reseptor inti. Reseptor ini berfungsi sebagai protein yang mengatur transkripsi yang diaktifkan oleh ligan. VDR secara selektif mengikat hormon 1,25-dihidroksivitamin D3 $\left(1,25(\mathrm{OH})_{2} \mathrm{D}_{3}\right)$ dan mengendalikan ekspresi gen yang dipilih dalam sel target (Dowd, Macdonald, \& Second, 2013; Pike, Meyer, Lee, Onal, \& Benkusky, 2017).

Konsentrasi kalsitriol $\left(1,25(\mathrm{OH})_{2} \mathrm{D}_{3}\right)$ dan kalsifediol $(25(\mathrm{OH}) \mathrm{D})$ berkorelasi secara signifikan dengan resistensi insulin. Selain itu, diidentifikasi bahwa keberadaan defisiensi vitamin D mempercepat resistensi insulin. Kalsitriol berperan pada imunomodulator yang melindungi terhadap kejadian DM melalui $V D R$ yang diekspresikan pada sel penyaji antigen, sel T aktivasi dan sel $\beta$ pankreas (Štefíková et al., 2011). VDR terdapat hampir di semua jaringan, termasuk sel $\beta$ pankreas. Hal ini sesuai dengan banyaknya peranan vitamin D termasuk regulasi sintesis dan sekresi insulin (Neelankal John \& Jiang, 2018). Jumlah gen $V D R$ yang ada di dalam tubuh tergantung pada gen $V D R$ yang diekspresikan di dalam sel. Untuk menentukan jumlah gen $V D R$ secara molekuler bisa menggunakan metode Real-Time PCR (RT-PCR) (Vural \& Maltas, 2012). Berdasarkan data peneliti bermaksud untuk melakukan penelitian kuantifikasi Peningkatan Gen Vitamin D Receptor (VDR) pada lansia Diabetes Mellitus tipe 2 dengan metode Real-Time PCR.

\section{METODE PELAKSANAAN}

Dalam penelitian ini menggunakan metode eksperimental laboratorik. Tahapan dalam penelitian, pasien mengisi informed consent dan kuisioner kemudian dilakukan tahapan pengambilan darah vena, isolasi DNA menggunakan kit spin kolom, konfirmasi hasil isolasi DNA dengan elektroforesis, dan amplifikasi serta kuantifikasi DNA menggunakan Real-Time PCR. Data yang diperoleh dari hasil Real-Time PCR berupa grafik amplifikasi DNA. Analisis data yang diperoleh dari hasil Real-Time PCR berupa nilai Cycle threshold $(\mathrm{Ct})$. Kuantifikasi 
peningkatan jumlah gen $V D R$ dihitung dengan menggunakan rumus : Rasio $=2^{\text {(Ct Normal-Ct DM) }}$ (Joyal, Black, \& Dassylva, 2010).

\section{HASIL DAN PEMBAHASAN}

Pada penelitian ini menggunakan 10 sampel pasien DM tipe 2 dan 1 sampel orang normal yang sudah bersedia dengan mengisi form informed consent dan lembar kuisioner. Pasien yang sudah bersedia selanjutnya diambil darah vena dan dilanjutkan dengan isolasi DNA menggunakan metode kit spin kolom. Isolasi DNA dari darah dilakukan dengan prosedur spin kolom geneaid dengan no katalog GB100 (Geneaid, 2017). Hasil isolasi DNA dikonfirmasi dengan menggunakan elektroforesis yang kemudian divisualisasi menggunakan UV transiluminator.

Hasil isolasi DNA menggunakan Kit spin kolom, kemudian di elektroforesis dan divisualisasi dengan UV transiluminator menghasilkan elektroferogram pada Gambar 1.

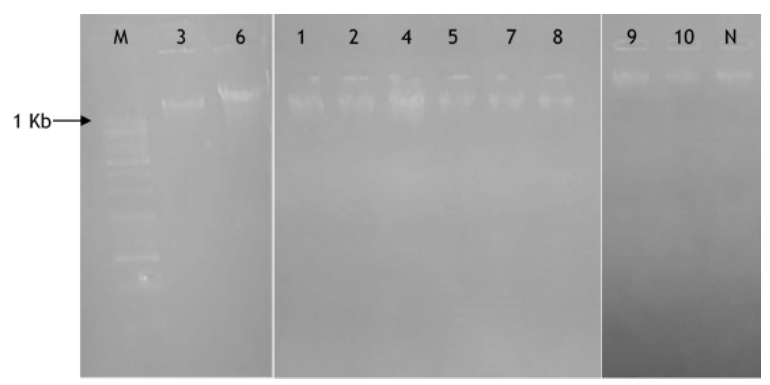

Gambar 1: Elektroferogram Hasil Isolasi DNA (Keterangan: $M=$ Marker DNA 1 Kb; $N=$ Sampel Normal; 1 -10 = Sampel DM Tipe 2)

Hasil elektroferogram menunjukkan terdapat pita DNA yang mengindikasikan bahwa proses isolasi berhasil dan murni dengan ditandai hanya terdapat 1 pita DNA. Isolat DNA dijadikan sebagai cetakan untuk amplifikasi gen VDR menggunakan Real-Time PCR. Tahapan Real-Time PCR terdiri dari denaturasi, penempelan, pemanjangan dan deteksi (Brown, 2018). Tahap denaturasi terjadi pemutusan ikatan hidrogen pada DNA cetakan dengan menggunakan suhu $95^{\circ} \mathrm{C}$, sehingga DNA untai ganda akan menjadi DNA untai tunggal. Pada tahap penempelan, primer reverse dan primer forward akan menempel pada DNA cetakan sesuai dengan target gen spesifik dalam penelitian ini adalah target gen VDR. Suhu untuk penempelan berbeda-beda tergantung pada kandungan GC, delta $\mathrm{G}$ dan melting temperature (Tm). Untuk gen $V D R$ digunakan suhu $60^{\circ} \mathrm{C}$ untuk penempelan yang diperoleh dari hasil 
optimasi sebelumnya. Setelah primer menempel, DNA polimerase akan memperpanjang DNA dengan menambahkan dNTP. DNA hasil amplifikasi akan dideteksi dengan menggunakan zat fluoresen SyBrGreen pada alat Real-Time PCR. Intensitas fluoresensi sebanding dengan jumlah salinan DNA (Brown, 2018; R Glick, Pasternak, \& Patten, 2010).

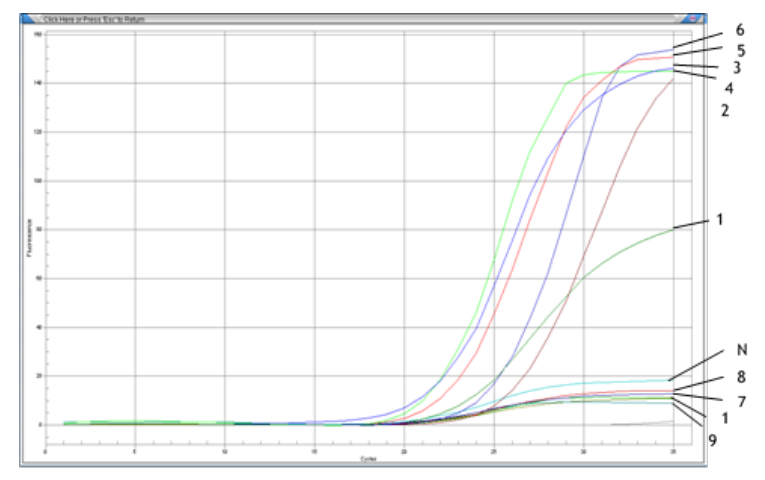

Gambar 2: Grafik Amplifikasi DNA Menggunakan Real-Time PCR

Peningkatan fluoresensi dapat dilihat dari garfik Real-Time PCR yang terdiri dari 3 fase yaitu fase linear, fase eksponensial, dan fase melandai. Pada fase linear, intensitas fluoresensi belum bisa dibedakan dari intensitas fluoresensi baseline pada siklus awal. Fluoresensi baseline diperoleh dari kontrol negatif Real-Time PCR. Fase eksponensial terjadi peningkatan intensitas fluoresensi sebanding dengan peningkatan jumlah salinan DNA. Fase melandai menunjukkan sudah tidak terjadi amplifikasi dimana tidak ada peningkatan intensitas fluoresensi pada siklus akhir (Brown, 2018; Maddocks, Jenkins, \& Pcr, 2017).

\section{Tabel 1.}

\section{Kuantifikasi Peningkatan Jumlah Gen VDR Pada Sampel DM Tipe 2}

\begin{tabular}{ccc}
\hline Kode & Nilai Ct & Rasio \\
\hline Normal & 21 & - \\
\hline $\mathbf{1}$ & 19 & 4,00 \\
\hline $\mathbf{2}$ & 20,79 & 1,16 \\
\hline $\mathbf{3}$ & 15,22 & 54,95 \\
\hline $\mathbf{4}$ & 16,86 & 17,63 \\
\hline $\mathbf{5}$ & 17,37 & 12,38 \\
\hline $\mathbf{6}$ & 19,41 & 3,01 \\
\hline $\mathbf{7}$ & 21,61 & 0,66 \\
\hline $\mathbf{8}$ & 21,38 & 0,77 \\
\hline $\mathbf{9}$ & 21,31 & 0,81 \\
\hline $\mathbf{1 0}$ & 21,32 & 0,80 \\
\hline
\end{tabular}


Dari grafik Real-Time PCR akan diperoleh nilai $\mathrm{Ct}$, nilai ini adalah batas siklus dimana sinyal fluoresensi dari DNA cetakan sudah melewati ambang batas intensitas fluoresensi baseline. Nilai $\mathrm{Ct}$ berbanding terbalik dengan jumlah DNA, semakin kecil nilai $\mathrm{Ct}$ semakin banyak jumlah DNA dalam sampel (Brown, 2018). Dari hasil penelitian nilai Ct pada orang normal 21, dan variatif pada $\mathrm{Ct} \mathrm{DM}$ tipe 2, sehingga rasio peningkatan jumlah gen $V D R$ menjadi variatif. Nilai Ct dipengaruhi oleh jumlah DNA cetakan, sehingga jika dilihat dari data Tabel 1 dapat disimpulkan bahwa jumlah gen $V D R$ dalam sampel berbeda-beda.

Jumlah gen $V D R$ di dalam tubuh dipengaruhi oleh genetik, vitamin $\mathrm{D}$ dan genotif FokI (O’Neill, Asani, Jeffery, Saccone, \& Bornman, 2013). Kekurangan vitamin D dapat mempengaruhi intoleransi glukosa, sensitifitas insulin baik secara langsung melalui aktivitas VDR dan genotif VDR atau secara tidak langsung memalui hormon kalsemik dan peradangan (Cheon et al., 2015; Hossein-Nezhad et al., 2014; Mackawy \& Badawi, 2014).

\section{SIMPULAN}

Berdasarkan hasil yang diperoleh dapat dihitung peningkatan jumlah gen $V D R$ pada penderita Diabetes Mellitus tipe 2, namun tidak dapat di rata-ratakan jumlah gen $V D R$, karena terdapat variasi jumlah peningkatan gen $V D R$.

\section{REFERENSI}

Brown, T. . (2018). Gene Cloning \& DNA Analysis. A John Wiley \& Sons.

Cheon, C. K., Nam, H. K., Lee, K. H., Kim, S. Y., Song, J. S., \& Kim, C. (2015). Vitamin D receptor gene polymorphisms and type 1 diabetes mellitus in a Korean population. Pediatrics International, 57(5), 870-874. https://doi.org/10.1111/ped.12634

Dowd, D. R., Macdonald, P. N., \& Second, C. (2013). Molecular and Cellular Endocrinology Handbook of Immunohistochemistry and in situ Hybridization of Human (Vol. 25).

Geneaid. (2017). Genomic DNA Mini Kit (Blood / Cultured Cell).

Hossein-Nezhad, A., Eshaghi, S. M., Maghbooli, Z., Mirzaei, K., Shirzad, M., Curletto, B., \& Chen, T. C. (2014). The role of vitamin D deficiency and vitamin D receptor genotypes on the degree of collateralization in patients with suspected coronary artery disease. 
BioMed Research International, 2014. https://doi.org/10.1155/2014/304250

Indra, T. A., Lydia, A., Purnamasari, D., \& Setiati, S. (2017). Asosiasi antara Status Vitamin D 25(Oh)D dengan Albuminuria pada Pasien Diabetes Melitus Tipe 2. Jurnal Penyakit Dalam Indonesia, 4(1), 16. https://doi.org/10.7454/jpdi.v4i1.108

Joyal, C. C., Black, D. N., \& Dassylva, B. (2010). Critical Factor for Successful Real-Time PCR. Sexual Abuse: Journal of Research and Treatment, 19(2), 155-173.

Kementerian Kesehatan RI Badan Penelitian dan Pengembangan. (2018). Hasil Utama Riset Kesehatan Dasar. Kementrian Kesehatan Republik Indonesia, 1-100. https://doi.org/1 Desember 2013

Khairani. (2019). Hari Diabetes Sedunia Tahun 2018. Pusat Data dan Informasi Kementrian Kesehatan RI, 1-8.

Khan H, Kunutsor S, Franco OH, C. R. (2013). Vitamin D, type 2 diabetes and other metabolic outcomes: a systematic review and meta-analysis of prospective studies. Proc Nutr Soc.

Kurniawan, L. B., Bahrun, U., \& Darmawaty. (2012). Hubungan Kadar Transaminase terhadap Mortalitas dan Lama Perawatan Pasien Infark Miokard Correlation between Serum Transaminase and Mortality and Length of Hospitalization in Myocardial Infarction Patients. Jurnal Kedokteran Yarsi, 20(1), 29-35.

Lestari, A. A. W. (2011). Resistensi Insulin: Definisi, Mekanisme dan Pemeriksaan Laboratoriumnya. Repositori Unud.Ac.Id, 1(2), 2-3.

Mackawy, A. M. H., \& Badawi, M. E. H. (2014). Association of vitamin D and vitamin D receptor gene polymorphisms with chronic inflammation, insulin resistance and metabolic syndrome components in type 2 diabetic Egyptian patients. Meta Gene, 2, 540-556. https://doi.org/10.1016/j.mgene.2014.07.002

Maddocks, S., Jenkins, R., \& Pcr, U. (2017). Real-Time Polymerase Chain Reaction Long Noncoding RNAs and Cancer. Gene.

Marinda, F. D., Suwandi, J. F., \& Karyus, A. (2016). Tatalaksana Farmakologi Diabetes Melitus Tipe 2 pada Wanita Lansia dengan Kadar Gula Tidak Terkontrol Pharmacologic Management of Diabetes Melitus Type 2 in Elderly Woman with Uncontrolled Blood Glucose. J Medula Unila, 5(2), 7. Diambil dari www.unila.ac

Neelankal John, A., \& Jiang, F. X. (2018). An overview of type 2 diabetes and importance of 
vitamin D3-vitamin D receptor interaction in pancreatic $\beta$-cells. Journal of Diabetes and its Complications, 32(4), 429-443. https://doi.org/10.1016/j.jdiacomp.2017.12.002

O’Neill, V., Asani, F. F., Jeffery, T. J., Saccone, D. S., \& Bornman, L. (2013). Vitamin D Receptor Gene Expression and Function in a South African Population: Ethnicity, Vitamin D and FokI. PLoS ONE, 8(6). https://doi.org/10.1371/journal.pone.0067663

Pike, J. W., Meyer, M. B., Lee, S. M., Onal, M., \& Benkusky, N. A. (2017). The Vitamin D receptor: Contemporary genomic approaches reveal new basic and translational insights. Journal of Clinical Investigation, 127(4), 1146-1154. https://doi.org/10.1172/JCI88887

R Glick, B., Pasternak, J. J., \& Patten, C. L. (2010). Molecular Biotechnology. ASM press.

Štefíková, K., Spustová, V., Krivošíková, Z., Okša, A., Gazdíková, K., Fedelešová, V., \& Dzúrik, R. (2011). Insulin resistance and vitamin D deficiency in patients with chronic kidney disease stage 2-3. Physiological Research, 60(1), 149-155. https://doi.org/10.33549/physiolres.931814

Suryanto, T., \& T, H. A. (2018). Hubungan antara Kadar 25 ( OH ) D 3 dan C-Peptida Berdasarkan Lama Sakit pada Anak dengan Diabetes Melitus Tipe 1 The Correlation between 25 ( OH ) D 3 and C-Peptide Levels Based on Illness Duration in Children with Type 1 Diabetes Mellitus, 30(1), 29-35.

Vural, H. C., \& Maltas, E. (2012). RT-qPCR assay on the vitamin D receptor gene in type 2 diabetes and hypertension patients in Turkey. Genetics and molecular research: GMR, 11(1), 582-590. https://doi.org/10.4238/2012.March.14.1 